\title{
Pengaruh Model Pembelajaran Circuit Learning Berbantuan Media Flip Chart terhadap Hasil Belajar IPA
}

\author{
Pt. Ayu Pramita ${ }^{1}$, I Km. Sudarma ${ }^{2}$, I Nym. Murda ${ }^{3}$ \\ 1,3 Jurusan Pendidikan Guru Sekolah Dasar, FIP \\ 2 Jurusan Teknologi Pendidikan, FIP \\ Universitas Pendidikan Ganesha \\ Singaraja, Indonesia \\ e-mail: putuayupramita0@gmail.com
}

\begin{abstract}
Abstrak
Permasalahan rendahnya hasil belajar IPA siswa kelas V SD di Gugus III Kecamatan Seririt menjadi masalah utama dilakukannya penelitian ini. Rendahnya hasil belajar IPA terjadi karena pembelajaran masih berpusat pada guru dan siswa cenderung pasif. Oleh karena itu, penelitian ini dilakukan dengan tujuan untuk mengetahui perbedaan hasil belajar IPA antara kelompok siswa yang dibelajarkan dengan model pembelajaran Circuit Learning berbantuan media flip chart dan kelompok siswa yang dibelajarkan dengan pembelajaran konvensional pada siswa kelas V semester II SD di Gugus III Kecamatan Seririt. Penelitian ini merupakan penelitian eksperimen semu dengan rancangan Nonequivalent Posttest-Only Control Group Design. Populasi penelitian adalah seluruh kelas V semester II di SD Gugus III Kecamatan Seririt tahun pelajaran 2017/2018 yang berjumlah 143 siswa. Sampel diambil dengan teknik random sampling. Sampel penelitian yaitu kelas V SD Negeri 2 Seririt sebagai kelas eksperimen yang berjumlah 22 siswa dan kelas VA SD Negeri 3 Seririt sebagai kelas kontrol yang berjumlah 25 siswa. Metode pengumpupulan data yang digunakan adalah metode tes. Data yang dikumpulkan dianalisis menggunakan analisis statistik deskriptif dan statistik inferensial. Hasil penelitian menunjukkan bahwa terdapat perbedaan hasil belajar IPA antara kelompok siswa yang dibelajarkan dengan model pembelajaran Circuit Learning berbantuan media flip chart dan kelompok siswa yang dibelajarkan dengan pembelajaran konvensional dengan thitung $=7,844$ lebih besar ttabel $=2,014$ denga taraf signifikansi $5 \%$. Berdasarkan hal tersebut, dapat disimpulkan bahwa model pembelajaran Circuit Learning berbantuan media flip chart berpengaruh terhadap hasil belajar IPA siswa
\end{abstract}

Kata kunci: Circuit Learning, Flip Chart, Hasil Belajar IPA.

\section{Abstract}

The low natural science learning achievement of the fifth-grade elementary school students in cluster III of Seririt district became the main reason of conducting this research. The low achievement was caused by learning style which still used teacher-centered as well as students' tendency of being passive. Hence, this study was aimed at investigating the difference of natural science learning achievement between students learning using Circuit Learning model helped with flip chart and those learning conventionally. This quasi experimental study used Nonequivalent Posttest-Only Control Group Design. The population of this study were all of the fifth-grade elementary school students (2nd semester) in cluster III of Seririt district in academic year 2017/2018 (143 students). Meanwhile, the samples of this study which were determined using random sampling technique were class $V$ of SDN 2 Seririt as the experimental class (22 students) and class VA of SDN 3 Seririt as the control class (25 students). Data collection was done through giving test. The obtained data were analyzed using both descriptive and inferential statistical analysis. The result shows that there is a difference on natural science learning achievement between the students who are taught using Circuit Learning model helped with flip chart and those who are taught conventionally. It is proven by the value of tobs which is higher than tcv $(7.844>2.014)$ at the alpha level of significance of $5 \%$. Thus, it can be concluded that Circuit Learning model helped with flip chart influences students' natural science learning achievement

Keywords: Circuit Learning, Flip Chart,Natural Science Learning Achievement. 


\section{Pendahuluan}

Sumber daya manusia yang berkualitas yakni sumber daya manusia yang kreatif, cerdas, terampil, berwawasan luas, disiplin, beriman, bertaqwa, mampu bersaing di dalam dunia kerja sesuai dengan perkembangan zaman, serta bertanggung jawab di dalam kehidupan. Sumber daya manusia yang berkualitas mutlak atau wajib dikembangkan dalam pembangunan bangsa, khususnya pembangunan di bidang pendidikan. Terkait dengan pengembangan sumber daya manusia yang berkualitas perlu terjadinya proses belajar yang baik. Terjadinya proses belajar yang baik, ditentukan oleh beberapa komponen yaitu, tenaga pendidik, anak didik, serta sarana-prasarana yang memadai. Tenaga pendidik merupakan "tenaga profesional yang mengerti dan memahami kemampuan siswanya serta berusaha untuk memberikan dan menggunakan model pembelajaran yang sesuai dengan kemampuan siswanya dan kondisi lingkungannya" (Ibrahim, 2017:200). Selanjutnya anak didik merupakan anak yang bersekolah untuk mengembangkan diri mereka. Kemudian "sarana dan prasarana berguna untuk menunjang penyelenggaraan proses belajar mengajar, baik secara langsung maupun tidak langsung dalam mencapai tujuan pendidikan" (Bahana Manajemen Pendidikan, 2014:661-831). Komponen tersebut dilibatkan secara langsung, dan saling memengaruhi satu dengan yang lainnya. Sehingga, terciptanya pembelajaran yang efektif dan efisien serta hasil belajar siswa menjadi lebih optimal.

Pembelajaran yang demikian harus terjadi pada semua mata pelajaran yang diterapkan di sekolah, termasuk mata pelajaran IPA. IPA yang sering disebut dengan pendidikan sains, merupakan salah satu mata pelajaran pokok dalam kurikulum pendidikan di Indonesia, termasuk pada jenjang sekolah dasar yang memiliki peranan penting dalam proses berkembangnya pengetahuan peserta didik. Secara garis besar hakikat IPA memiliki tiga komponen yaitu IPA sebagai produk, IPA sebagai proses, dan IPA sebagai sikap ilmiah. IPA sebagai produk berupa fakta-fakta, konsep-konsep, prinsip-prinsip, dan hukum-hukum, IPA sebagai proses maksudnya adalah bagaimana proses mendapatkan IPA itu sendiri, dan IPA sebagai sikap ilmiah adalah rasa ingin tahu, kerja sama, pengetahuan baru, dan tanggung jawab (Sudana, dkk, 2016). Maka dari itu, IPA sangat penting diajarkan kepada siswa dimulai dari jenjang pendidikan dasar karena melalui mata pelajaran IPA, siswa dilatih untuk memiliki keterampilan mengamati dan bereksperimen. Pada pembelajaran IPA, juga dilatih untuk memiliki sikap ilmiah seperti sikap jujur. Oleh karena pentingnya pendidikan IPA di SD, maka sangat diperlukan pembelajaran yang sesuai karakteristiknya, sehingga siswa belajar IPA secara bermakna.

Namun fakta yang ditemukan di sekolah, hasil belajar siswa masih belum sesuai harapan. Hal ini diketahui dari hasil wawancara, observasi dan pencatatan dokumen yang dilaksanakan pada tanggal 15 November hingga 22 November 2017 terhadap tujuh orang guru kelas V yang berada di Gugus III Kecamatan Seririt Kabupaten Buleleng Tahun Pelajaran 2017/2018. Hasil wawancara yang didapatkan yaitu: 1) tiga dari tujuh orang guru mengaku kurang mengetahui bagaimana menciptakan pola pembelajaran yang menyenangkan, aktif dan kreatif sehingga pembelajaran menjadi pasif, 2) tujuh orang guru cenderung menggunakan metode ceramah, diskusi, tanya jawab, dan penugasan secara terus menerus selama pembelajaran agar materi lebih cepat diajarkan sehingga tidak ada materi yang belum diajarkan sebelum ulangan akhir mengingat materi yang harus disampaikan oleh guru kompleks dengan waktu yang terbatas, dan siswa tidak sepenuhnya memahami materi yang telah diberikan oleh guru dalam pembelajaran, sehingga kegiatan pembelajaran tidak berjalan dengan maksimal. Hal ini didukung oleh Republika (2015) yang menyatakan bahwa meskipun telah melalui pergantian kurikulum selama beberapa kali, masih ada guru-guru yang setia menerapkan metode pembelajaran tradisional saat mengajar. Kebiasaan mengajar masih dominan menempatkan guru sebagai subjek, sedangkan murid atau siswa berperan sebagai objek. Suparman (dalam Republika, 2015) menyatakan, banyak praktik pembelajaran guru- 
guru yang tidak berorientasi pada pengembangan keragaman potensi anak melainkan hanya didasarkan pada bagaimana guru menyelesaikan target-target kurikulum sehingga, pada akhirnya berorientasi pada kepentingan guru.

Hasil wawancara diperkuat dengan hasil observasi, didapatkan hasil observasi sebagai berikut. Pertama, hanya beberapa siswa yang mau mengangkat tangan untuk memberikan pendapat atas pertanyaan yang diberikan guru selain itu, siswa enggan untuk bertanya apabila menemukan kesulitan atau belum mengerti dengan penjelasan guru. Kedua, proses pembelajaran kurang efektif dan kondusif serta kurang mengarahkan siswa agar mampu mengkontruksi pengalaman kehidupan sehari-hari ke dalam pembelajaran di kelas, sehingga materi yang diberikan tidak lama diingat oleh siswa. Ketiga, guru tidak menggunakan media sehingga pembelajaran menjadi monoton dan membuat siswa mudah jenuh. Keempat, siswa tidak dapat menjelaskan kembali tentang konsep materi pembelajaran yang telah dipelajari, hal ini disebabkan karena minimnya pengetahuan siswa dalam mencari ide pokok dari persoalan yang diberikan sehingga siswa mengalami kesulitan dalam penyampaian materi yang sudah diajarkan.

Selain observasi dan wawancara, dilakukan pencatatan dokumen. Pencatatan dokumen diperoleh dari hasil nilai rata-rata Ulangan Tengah Semester (UTS) mata pelajaran IPA dari tujuh guru kelas V pada semester ganjil tahun pelajaran 2017/2018. Adapun rata-rata nilai UTS mata pelajaran IPA siswa kelas V SD Gugus III Kecamatan Seririt, Kabupaten Buleleng dengan KKM 60-70, disajikan pada tabel 1.

Tabel 1. Rata-rata Nilai UTS IPA kelas V di SD Gugus III Kecamatan Seririt. Kabupaten Buleleng Tahun Pelajaran 2017/2018

\begin{tabular}{|c|c|c|c|c|c|c|c|}
\hline \multirow{2}{*}{$\begin{array}{l}\text { SD di Gugus III } \\
\text { Kecamatan Seririt }\end{array}$} & \multirow{2}{*}{$\begin{array}{l}\text { Jumlah } \\
\text { Siswa }\end{array}$} & \multirow{2}{*}{$\begin{array}{c}\text { KKM Mata } \\
\text { Pelajaran } \\
\text { IPA Kelas } \\
\text { V }\end{array}$} & \multirow{2}{*}{$\begin{array}{l}\text { Nilai } \\
\text { Rata- } \\
\text { rata } \\
\text { UTS }\end{array}$} & \multicolumn{2}{|c|}{ Tuntas } & \multicolumn{2}{|c|}{ Tidak Tuntas } \\
\hline & & & & Siswa & $\%$ & Siswa & $\%$ \\
\hline SDN 1 Seririt A & 25 & 70 & 70,88 & 14 & 56 & 11 & 44 \\
\hline SDN 1 Seririt B & 18 & 70 & 69,11 & 12 & 66,67 & 6 & 33,33 \\
\hline SDN 2 Seririt & 22 & 60 & 62,95 & 13 & 59,09 & 9 & 40,91 \\
\hline SDN 3 Seririt A & 25 & 60 & 62,60 & 17 & 68 & 8 & 32 \\
\hline SDN 3 Seririt B & 17 & 60 & 64.64 & 10 & 58,82 & 7 & 41,18 \\
\hline SDN 1 Pengastulan & 21 & 65 & 64.05 & 11 & 52,38 & 10 & 47,62 \\
\hline SDN 3 Pengastulan & 15 & 65 & 64,33 & 9 & 60 & 6 & 40 \\
\hline Jumlah & 143 & & & 86 & 60,14 & 57 & 39,86 \\
\hline
\end{tabular}

Berdasarkan Tabel 1 terlihat bahwa rata-rata nilai UTS dalam kategori rendah sehingga hasil belajar IPA siswa kelas $\mathrm{V}$ belum maksimal dan perlu ditingkatkan. Oleh karena itu, hasil belajar siswa yang masih dalam kategori rendah perlu dicarikan suatu solusi. Salah satu solusi yang digunakan adalah model pembelajaran yang lebih inovatif yang mampu menciptakan suasana belajar yang aktif. Sejalan dengan hal tersebut, pembelajaran inovatif diharapkan dapat menarik minat siswa untuk mempelajari IPA dan dapat mendorong siswa untuk lebih berperan aktif dalam belajar, sehingga akan membawanya untuk menemukan sendiri jawaban dari suatu permasalahan dan siswa akan lebih lama mengingat materi yang diberikan oleh guru serta berdampak pada kemajuan hasil belajarnya.

Salah satu model pembelajaran yang dapat ditawarkan adalah model pembelajaran Circuit Learning. Model pembelajaran Circuit Learning adalah model pembelajaran yang menuntun siswa dalam menerima pembelajaran dengan memaksimalkan dan mengupayakan pemberdayaan pikiran dan perasaan melalui pola penambahan (adding) dan pengulangan (repetition) yang dilaksanakan dalam situasi belajar kondusif dan fokus. De Porter (2010) 
menyatakan bahwa model pembelajaran Circuit Learning bertujuan untuk mengajarkan keadaan prima dalam belajar sehingga mencegah rasa takut, jenuh, pikiran negatif, bosan dan tidak percaya diri dalam belajar. Linda (2017) menyatakan, model pembelajaran ini menekankan belajar dalam kelompok heterogen saling membantu satu sama lain, bekerja sama menyelesaikan masalah dalam menyatukan pendapat untuk memeroleh keberhasilan yang optimal baik kelompok maupun individu.

Model pembelajaran ini dapat didukung dengan berbantuan media flip chart. Flip chart adalah lembaran kertas berisikan bahan pelajaran yang disusun dengan baik dan rapi menjadi satu bundel dengan ukuran yang sama dan diikat pada bagian atasnya, cara menunjukkannya dengan dibalik satu per satu. Flip chart merupakan "salah satu media cetakan yang sangat sederhana dilihat dari proses pembuatannya dan penggunannya yang relatif mudah dengan memanfaatkan bahan kertas yang mudah kita jumpai di lingkungan sekitar kita serta cukup efektif karena flip chart dapat dijadikan sebagai media (pengantar) pesan pembelajaran yang secara terencana ataupun secara langsung disajikan pada flip chart "(Susilana dan Riyana, 2007)

Berdasarkan hal tersebut, model pembelajaran Circuit Learning berbantuan media flip chart memiliki pengaruh terhadap hasil belajar siswa. Namun besarnya pengaruh model pembelajaran Circuit Learning dengan flip chart belum dapat diketahui. Berdasarkan pemikiran tersebut, maka dilakukan penelitian yang berjudul "Pengaruh Model Pembelajaran Circuit Learning Berbantuan Media Flip Chart Terhadap Hasil Belajar IPA pada Siswa Kelas V Semester II di SD Gugus III Kecamatan Seririt Tahun Pelajaran 2017/2018".

\section{Metode}

Penelitian ini dilaksanakan di kelas V SD N 2 Seririt dan di kelas VA SD N 3 Seririt di Gugus III Kecamatan Seririt. Penelitian dilaksanakan pada rentang waktu semester genap Tahun Pelajaran 2017/2018 yang dilaksanakan pada tanggal 2 April 2018 hingga 2 Mei 2018.

Jenis penelitian ini adalah penelitian eksperimen semu (quasi experiment). Penelitian ini menggunakan desain Nonequivalent Posttest-Only Control Group Desain. Terdapat dua kelompok dalam penelitian ini yang dipilih secara acak. Kelompok pertama diberi perlakuan (X) menggunkan model pembelajaran Circuit Learning berbantuan media flip chart dan kelompok yang lain tidak diberikan perlakuan (-) menggunakan model pembelajaran Circuit Learning berbantuan media flip chart. Kelompok yang diberikan perlakuan disebut kelompok eksperimen dan kelompok yang tidak diberikan perlakuan disebut kelompok kontrol.

Pelaksanaan penelitian ini terdiri dari tiga tahap yakni tahap persiapan, tahap pelaksanaan, dan tahap pelaporan. Tahap persiapan terdiri dari merancang perangkat pembelajaran dan instrumen yang digunakan untuk penelitian,

mengonsultasikan perangkat pembelajaran dan instrumen dengan pembimbing dan pakar, menguji instrumen yang digunakan untuk penelitian, melakukan analisis uji instrumen, merevisi instrumen penelitian yang telah dilakukan. Pada tahap pelaksanaan pertemuan diadakan sebanyak 8 kali pertemuan. 7 kali pertemuan untuk memberikan treatment dan 1 kali pertemuan untuk pemberian posttest. Langkah-langkah yang dilakukan pada tahap ini adalah memberikan perlakuan model Circuit Learning berbantuan media flip chart pada kelas eksperimen dan pembelajaran konvensional pada kelas kontrol, kemudian mengadakan posttest pada kelas eksperimen dan kelas kontrol. Pada tahap pelaporan yang dilakukan adalah melakukan analisis data dilanjutkan dengan pengujian hipotesis sesuai data yang diperoleh dan menyusun laporan penelitian sesuai dengan analisis data yang didapatkan.

Populasi dalam penelitan ini adalah seluruh siswa kelas V di SD Gugus III Kecamatan Seririt tahun pelajaran 2017/2018 yang berjumlah 143 orang siswa. Sampel yang digunakan telah diuji kesetaraannya menggunakan analisis varians satu jalur (Anava $A$ ) dengan hasil fhitung $=1,28$ lebih kecil dari ftabel=2,17. Sampel penelitian ini adalah siswa kelas $V$ di SD Negeri 2 Seririt yang berjumlah 22 orang sebagai kelompok eksperimen dan siswa kelas VA di SD Negeri 3 Seririt yang berjumlah 25 orang sebagai kelompok kontrol yang dipilih dengan teknik random sampling. Dalam penelitian ini terdapat dua variabel yakni variabel bebas dan 
variabel terikat. Model pembelajaran Circuit Learning berbantuan media flip chart sebagai variabel bebas dan hasil belajar IPA sebagai variabel terikat.

Metode pengumpulan data yang digunakan dalam penelitian ini adalah metode tes dengan memberikan tes pilihan ganda setelah diberlakukannya model pembelajaran Circuit Learning berbantuan media flip chart dan pembelajaran konvensional. Instrumen penelitian perlu diuji cobakan terlebih dahulu untuk mengetahui kelayakan instrumen tersebut. Suatu instrumen dikatakan layak digunakan jika memenuhi syarat instrumen yang baik. Maka dari itu, perlu dilakukan uji validitas tes, uji reliabilitas tes, uji tingkat kesukaran tes, dan uji daya beda tes. Uji validitas isi dilakukan dengan cara konsultasi kepada dua pakar (judges) terkait dengan soal untuk mengukur hasil belajar dengan hasil perhitungan 1,00 dengan kategori sangat tinggi, Kemudian tes hasil belajar diuji cobakan ke sekolah. Berdasarkan hasil uji validitas butir tes dengan jumlah responden sebanyak 90 siswa didapatkan 36 butir tes valid dari 40 butir tes yang dujicobakan. Selanjutnya dari hasil uji reliabilitas diperoleh koefisien reliabilitas sebesar 0,885 dengan kategori sangat tinggi. Kemudian, berdasarkan hasil uji coba tingkat kesukaran butir tes hasil belajar IPA diperoleh 11 butir soal tergolong mudah, 26 butir soal tergolong sedang, dan 3 butir soal tergolong sukar. Hasil perhitungan taraf kesukaran tes (Pp) adalah 0,58 dengan kriteria sedang. Selanjutnya hasil uji daya beda butir tes hasil belajar IPA, diperoleh 7 butir soal terklarifikasi kurang baik, 14 butir soal terkklarifikasi cukup baik, dan 19 butir soal terklarifikasi baik. Hasil perhitungan daya beda tes (Dp) adalah 0,34 dengan kriteria cukup baik.

Pada penelitian ini digunakan dua metode analisis yaitu analisis statistik deskriptif dan analisis statistik inferensial. Metode analisis yang digunakan untuk menguji hipotesis dalam penelitian ini adalah uji-t sampel independent (tidak berkorelasi). Sebelum dilakukan uji hipotesis dengan metode statistik inferensial, terlebih dahulu dilakukan uji prasyarat analisis meliputi uji normalitas sebaran data dengan menggunakan uji Chi-Kuadrat dan uji homogenitas varians dengan menggunakan uji F.

\section{Hasil dan Pembahasan}

Data hasil belajar IPA kelompok eksperimen diperoleh melalui posttest terhadap 22 orang siswa. Hasil tersebut menunjukkkan skor tertinggi adalah 30 dan skor terendah adalah 21. Dari skor yang diperoleh dapat dideskripsikan yaitu mean (M), median (Md), modus (Mo), standar deviasi (s), dan varians $\left(s^{2}\right)$. Data hasil belajar IPA kelompok eksperimen dapat disajikan ke dalam bentuk kurva Polygon seperti gambar 1.

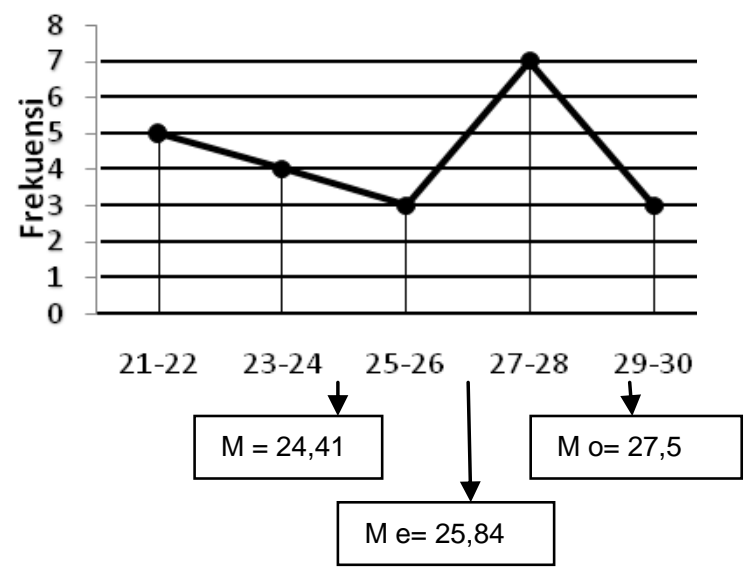

\section{Gambar 1. Kurva Polygon Hasil Belajar IPA Kelompok Eksperimen}

Berdasarkan kurva polygon di atas, dapat diketahui $M o>M d>M$, sehingga kurva yang terbentuk adalah kurva juling negatif. Artinya skor yang diperoleh cenderung tinggi. Data hasil belajar IPA kelompok kontrol diperoleh melalui posttest terhadap 25 orang siswa. Hasil tersebut menunjukkan skor tertinggi 25 dan skor terendah 10. Dari skor yang diperoleh dapat 
dideskripsikan yaitu mean (M), median (Me), modus (Mo), standar deviasi (s), varians $\left(\mathrm{s}^{2}\right)$, data hasil belajar IPA kelompok kontrol dapat disajikan ke dalam bentuk kurva polygon seperti gambar 2

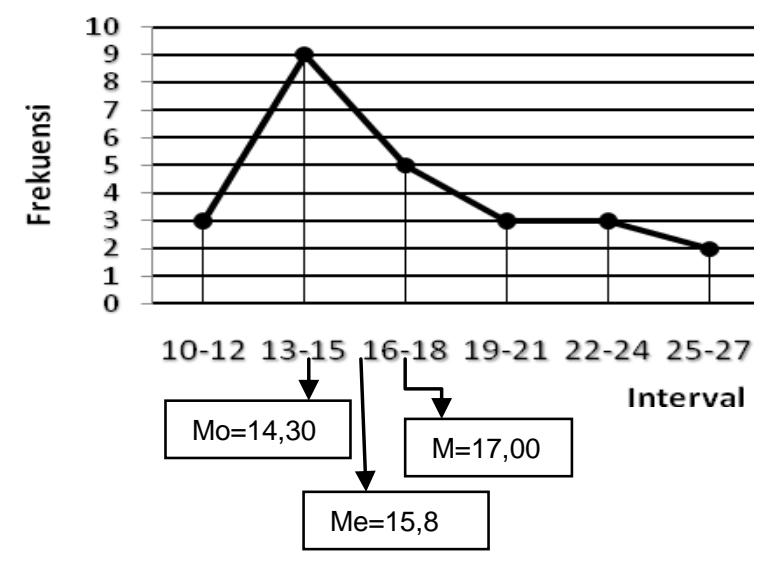

Gambar 2. Kurva Polygon Data Hasil Belajar IPA Kelompok Kontrol

Berdasarkan kurva polygon di atas, dapat diketahui $\mathrm{Mo}<\mathrm{Md}<\mathrm{M}$, sehingga kurva yang terbentuk adalah kurva juling positif. Artinya skor yang diperoleh dakah cenderung rendah.

Berdasarkan uraian deskripsi data hasil belajar IPA kelompok eksperimen dan kelompok kontrol dapat ditentukan tinggi rendahnya kualitas kedua variabel tersebut. Untuk menentukan tinggi rendahnya kualitas variabel maka skor rata-rata (mean) tiap-tiap variabel dikonversikan dengan menggunakan kriteria rata-rata ideal $\left(\mathrm{M}_{\mathrm{i}}\right)$ standar deviasi ideal $\left(\mathrm{SD}_{\mathrm{i}}\right)$. Sebelum dimasukkan ke dalam konversi skala lima, terlebih dahulu dihitung rata-rata skor (mean) dan standar deviasi (SD). Adapun penentuan tinggi rendahnya hasil belajar IPA kelompok eksperimen dan kelompok kontrol dengan kualifikasi menggunakan pedoman konversi skala lima dapat disajikan pada tabel 2

Tabel 2. Kategori Data Hasil Belajar IPA Kelompok Eksperimen dan Kelompok Kontrol

\begin{tabular}{cc}
\hline Rentang Skor & Kategori \\
$22,5 \leq \bar{X} \leq 30$ & Sangat Tinggi \\
$17,5 \leq \bar{X} \leq 22,5$ & Tinggi \\
$12,5 \leq \bar{X} \leq 17,5$ & Sedang \\
$7,5 \leq \bar{X} \leq 12,5$ & Rendah \\
$0 \leq \bar{X} \leq 7,5$ & Sangat Rendah \\
\hline
\end{tabular}

Nilai rata-rata hasil belajar IPA pada kelompok eksperimen yang dibelajarkan dengan pembelajaran konvensional adalah 25,41. Berdasarkan tabel 2 rata-rata $(X)$ skor hasil belajar pada mata pelajaran IPA kelompok eksperimen terletak pada kategori sangat tinggi yaitu $22,5 \leq$ $\bar{X} \leq 30$.

Sedangkan, nilai rata-rata hasil belajar IPA kelompok kontrol yang dibelajarkan dengan pembelajaran konvensional adalah 17,00. Berdasarkan tabel 2 rata-rata $(X)$ skor hasil belajar IPA kelompok kontrol terletak pada kategori sedang yaitu $12,5 \leq \bar{X} \quad \leq 17,5$.

Berdasarkan analisis data yang dilakukan, dapat disajikan hasil uji normalitas sebaran data hasil belajar IPA kelompok eksperimen dan kelompok kontrol pada Tabel 3 
Tabel 3. Rangkuman Hasil Uji Normalitas Sebaran Data Skor Hasil Belajar IPA

\begin{tabular}{ccccc}
\hline No. & $\begin{array}{c}\text { Kelompok Data Hasil } \\
\text { Belajar }\end{array}$ & $\chi^{2}{ }_{\text {hitung }}$ & $\begin{array}{c}\chi_{\text {tabel } \text { dengan Taraf }}^{\text {Signifikansi 5\% }} \\
\text { Sigan }\end{array}$ & Keterangan \\
\hline 1. & Kelompok Eksperimen & 3,04 & 5,591 & Normal \\
2. & Kelompok Kontrol & 6,17 & 7,815 & Normal \\
\hline
\end{tabular}

Berdasarkan hasil perhitungan menggunakan rumus Chi-Kuadrat, diperoleh bahwa data data skor hasil belajar IPA kelompok eksperimen dan kelompok kontrol berdistribusi normal

Pada penelitian ini, uji homogenitas dilakukan terhadap varians antarkelompok eksperimen dan kelompok kontrol. Uji yang digunakan adalah uji $\mathrm{F}$ dengan kriteria data homogen jika $F_{\text {hitung }}<F_{\text {tabel }}$. Rekapitulasi hasil uji homogenitas varians antarkelompok eksperimen dan kelompok kontrol disajikan pada tabel

Tabel 4. Rangkuman Hasil Uji Homogenitas Varians Skor Hasil Belajar IPA

\begin{tabular}{ccccc}
\hline Kelompok Data Hasil Belajar & Varians & $F_{\text {hitung }}$ & $\begin{array}{c}F_{\text {tabel }} \text { dengan Taraf } \\
\text { Signifikansi 5\% }\end{array}$ & Status \\
\hline Kelompok Eksperimen & 8,92 & \multirow{2}{*}{1,95} & 2,03 & Homogen \\
\hline Kelompok Kontrol & 17,42 & & 2,03 & \\
\hline
\end{tabular}

Berdasarkan Tabel 4, dapat diketahui bahwa varians data hasil belajar IPA kelompok eksperimen dan kelompok kontrol adalah homogen.

Untuk pembuktian hipotesis yang diajukan dilakukan pengujian dengan menggunakan uji-t sampel independet (tidak berkorelasi) dengan rumus polled varians. Adapun hasil analisi uji-t disajikan pada Tabel 5

Tabel 5. Rangkuman Hasil Perhitungan Uji-t Hasil Belajar IPA

\begin{tabular}{lccccccc}
\hline $\begin{array}{c}\text { Kelompok Data Hasil } \\
\text { Belajar }\end{array}$ & $\begin{array}{c}\text { Mean } \\
(\bar{X})\end{array}$ & $\mathrm{s}^{2}$ & $\mathrm{~N}$ & $\mathrm{Db}$ & $\mathrm{t}_{\text {hitung }}$ & $\mathrm{t}_{\text {tabel }}$ & Kesimpulan \\
\hline Kelompok EKsperimen & 25,41 & 8,92 & 22 & 45 & 7,844 & 2,014 & $\begin{array}{c}\mathrm{t}_{\text {hitung }}>\mathrm{t}_{\text {tabel }} \mathrm{H}_{0} \\
\text { ditolak }\end{array}$ \\
\hline Kelompok Kontrol & 17,00 & 17,42 & 25 & 45 &
\end{tabular}

Berdasarkan Tabel 5 dapat diketahui $t_{\text {hit }}$ lebih besar dari $t_{\text {tab }}\left(t_{\text {hit }}>t_{\text {tab }}\right)$, sehingga $H_{0}$ ditolak dan $\mathrm{H}_{1}$ diterima. Dengan demikian, terdapat perbedaan yang signifikan hasil belajar IPA antarkelompok siswa yang dibelajarkan dengan model pembelajaran Circuit Learning berbantuan media flip chart dan kelompok siswa yang dibelajarkan dengan pembelajaran konvensional pada siswa kelas V di SD Gugus III Kecamatan Seririt Tahun Pelajaran 2017/2018. 
Berdasarkan penelitian yang dilakukan, terdapat perbedaan rata-rata hasil belajar IPA pada kelompok eksperimen dan kelompok kontrol. Secara deksriptif, hasil belajar IPA kelompok eksperimen lebih tinggi dibandingkan dengan kelompok kontrol. Perbedaan tersebut menunjukkan bahwa model pembelajaran Circuit Learning berbantuan media flip chart berpengaruh terhadap hasil belajar IPA siswa kelas V. Perbedaan hasil belajar tersebut disebabkan oleh beberapa faktor sebagai berikut.

Pertama, pembelajaran yang menggunakan model pembelajaran Circuit Learning dapat mengubah pembelajaran yang awalnya berpusat pada guru menjadi berpusat pada siswa. Siswa menjadi lebih aktif dalam proses pembelajaran. Hal ini sesuai dengan pendapat Linda (2017) yang menyatakan, dalam model Circuit Learning banyak kegiatan pembelajaran yang membuat siswa untuk berpikir kreatif, dan menyenangkan serta selalu berinteraksi dengan guru sehingga proses pembelajaran tidak berjalan satu arah melainkan ada timbal balik. Kemudian Kristiarti (2015) menyatakan model pembelajaran Circuit Learning adalah model pembelajaran yang berpusat pada siswa, dimana model pembelajaran ini dapat menambah kreativitas siswa dan mengaktifkan siswa karena membuat pengetahuan siswa yang didapat dalam pembelajaran dialami sendiri oleh siswa sehingga menjadi bermakna dan sulit dilupakan.

Kedua, model pembelajaran Circuit Learning terdiri dari empat tahapan pembelajaran yaitu: kondisikan situasi belajar kondusif dan fokus, membuat catatan kreatif, tanya jawab dan refleksi. Keempat tahapan tersebut dapat meningkatkan kreativitas siswa dalam merangkai kata dengan bahasa sendiri dan melatih konsentrasi siswa untuk fokus dalam belajar serta menumbuhkembangkan kemampuan pemahaman konsep dan komunikasi peserta didik. Pada tahap pertama dalam proses pembelajaran guru mengkondisikan situasi belajar kondusif dan fokus. Pada tahap ini guru menciptakan suasana belajar yang nyaman dan aman dengan memberikan salam, mengecek kehadiran siswa, mengajak siswa berdoa sebelum memulai pembelajaran dan memberikan apersepsi mengenai materi yang akan dipelajari yang berkaitan dengan lingkungan sekitar siswa. Hal tersebut dilakukan agar siswa merasa gembira dan antusias dalam mengikuti proses pembelajaran bukannya merasa tegang dan tertekan. Hal ini sesuai dengan pendapat De Porter (2010) yang menyatakan, untuk menghilangkan rasa takut dan pikiran negatif, maka pembelajaran harus dimulai dengan keadaan pikiran yang fokus dan percaya diri. Ketika siswa dalam keadaan prima maka siswa akan lebih mudah menanamkan informasi dalam benak mereka. Berikutnya, Mustafida (2017) mengungkapkan bahwa suasana kelas yang kondusif menjadi komponen penting yang menjadikan proses pembelajaran dapat berjalan dengan baik karena dapat menghindarkan siswa dari perasaan tidak betah, tegang, tertekan, bahkan perasaan terancam dalam belajar.

Pada tahap kedua, siswa membuat catatan kreatif dengan menuliskan ide-ide pokok materi yang diperolehnya setelah membaca buku. Menulis dapat membantu merealisasikan tujuan pembelajaran yaitu siswa menjadi lebih paham mengenai materi yang ia pelajari dan dapat meningkatkan daya ingat siswa. Hal ini sesuai dengan pendapat Moidady (2014) yang mengungkapkan bahwa tujuan menulis yakni dapat meningkatkan pengetahuan dan wawasan siswa serta menumbuhkan kreatifitas siswa dalam mengungkapkan ide, gagasan serta menginformasikan segala sesuatu baik itu fakta, data maupun peristiwa sehingga pembaca memperoleh pengetahuan baru. Selain itu, Dewi (2014) menyatakan, ketika siswa merekam apa yang dilihat dan didengar, kemudian dituliskan kembali ke dalam bentuk catatan sesuai dengan gaya tulisan siswa masing-masing dapat dikatakan kemampuan daya ingat siswa lebih tinggi dibandingkan siswa yang tidak mencatat.

Pada tahapan ketiga, dilaksanakan kegiatan tanya jawab, baik siswa yang mengajukan pertanyaan kepada guru ataupun sebaliknya. Dengan adanya kegiatan tanya jawab membantu siswa mengetahui bagian-bagian materi yang perlu diketahui dan diingat sehingga jalan pikiran siswa akan terbuka dalam merumuskan kalimat secara sistematis dengan bahasa yang baik serta dapat melatih daya nalar siswa itu sendiri. Kamelia (2017: 151) menyatakan "tanya jawab dapat melatih kemampuan berpikir siswa, sehingga siswa dapat meningkatkan hasil belajarnya". Selanjutnya siswa diberikan kesempatan untuk 
mengomunikasikan hasil pemikirannya melalui kegiatan kelompok untuk mendiskusikan lembar kerja siswa (LKS) yang diberikan oleh guru. Dalam diskusi ini siswa saling memberikan tanggapan atau pendapat terkait masalah yang tertera pada LKS sehingga terjadi pertukaran ide dan interaksi antarsiswa dapat berlangsung secara efektif dalam proses pembelajaran. Armini (2017:8) menyatakan "ketika siswa mampu mengomunikasikan hasil pemikirannya, secara tidak langsung siswa dapat menumbuhkembangkan kemampuan komunikasi yang dimilikinya karena siswa diberikan kesempatan menyampaikan pendapat sesuai dengan bahasanya sendiri".

Pada tahap keempat adalah refleksi, yang mana guru memberikan penguatan kepada siswa. Penguatan memberikan kesan pada siswa bahwa usaha yang mereka lakukan selama pembelajaran patut dihargai. Penguatan yang diberikan meliputi pujian atau hadiah kepada siswa yang mengerjakan tugas dengan baik dan memberikan semangat kepada siswa yang belum mendapat pujian atau hadiah untuk berusaha lebih giat lagi. Penguatan tersebut mengakibatkan siswa semakin termotivasi belajar, sehingga siswa semakin aktif dalam belajar dan berdampak pada hasil belajar siswa. Usman (dalam Nur, 2013:210) menyatakan "penguatan mempunyai pengaruh yang positif terhadap proses belajar mengajar siswa dan bertujuan untuk meningkatkan perhatian siswa terhadap pelajaran, merangsang dan meningkatkan motivasi belajar, meningkatkan kegiatan belajar, serta membina tingkah laku siswa yang produktif'. Selain itu, Nur (2013) menyatakan bahwa penguatan dalam kelas juga bertujuan untuk memudahkan peserta didik dalam belajar. Hal ini dikarenakan pemberian penguatan yang dilakukan oleh guru akan membuat peserta didik merasa dihargai sehingga muncul perasaan senang yang akan mendorong siswa untuk belajar hal-hal baru.

Ketiga, penggunaan media flip chart. Dengan menggunakan media ini dapat meningkatkan aktivitas belajar serta dapat menjaga perhatian siswa agar tetap fokus karena media flip chart berisi gambar-gambar berwarna yang lebih menarik sesuai dengan materi pelajaran yang dibahas. Hal tersebut terlihat ketika banyak siswa yang mengangkat tangan saat diberikan kesempatan untuk bertanya dan menjawab pertanyaan yang disampaikan guru berdasarkan materi yang di pasang pada media flip chart. Hal ini sesuai dengan pendapat Herditiya (2018:25) menyatakan bahwa "media flip chart dapat membantu dalam meningkatkan hasil belajar siswa serta aktivitas belajar siswa karena memiliki tampilan gambar yang menarik siswa lebih berantusias untuk menggali informasi dan memecahkan masalah". Selanjutnya Susilana, dkk (dalam Pratiwi, 2013) menyatakan, media flip chart mampu menyajikan pesan pembelajaran secara ringkas dan praktis yang mencakup pokokpokok materi pembelajaran dengan tujuan memfokuskan perhatian siswa dan membimbing alur materi yang disajikan.

Berbeda halnya dengan siswa yang dibelajarkan dengan pembelajaran konvensional, yang bercirikan pembelajaran berpusat pada guru (teacher centered). Pada pembelajaran ini guru lebih banyak mendominasi kegiatan pembelajaran, guru sangat aktif dari merencanakan, melaksanakan, dan sampai pada evaluasi, sedangkan siswa lebih banyak mendengarkan penjelasan guru serta mengamati kegiatan yang dilakukan guru. Dalam hal ini pembelajaran yang berpusat pada guru menyebabkan siswa menjadi pasif karena siswa hanya berperan sebagai pendengar dan penerima informasi yang diberikan oleh guru.

Adapun kendala yang dihadapi selama melaksanakan penelitian di kelompok eksperimen yaitu guru masih melihat RPP untuk mengetahui langkah-langkah yang dilakukan selama pembelajaran. Permasalahan ini dapat diatasi dengan mengadakan simulasi 10 menit sebelum pembelajaran dimulai untuk mengingat kembali langkah-langkah pembelajaran yang harus dilaksanakan, kemudian masih ada siswa yang ragu-ragu untuk mengangkat tangan ketika ingin bertanya atau mengajukan pendapat, hal ini diatasi dengan memotivasi siswa agar mereka mau untuk mengangkat tangan. Selanjutnya ketika berdiskusi mengerjakan LKS ada beberapa siswa yang hanya diam dan melihat temannya mengerjakan, hal ini diatasi dengan memberikan semua siswa LKS sehingga semua siswa mau berdiskusi dan menuliskan hasil diskusinya bersama-sama. 
Hasil penelitian ini didukung pula oleh penelitian yang pernah dilakukan oleh Sari (2017) yang menyatakan bahwa hasil belajar IPS siswa kelas V dengan model pembelajaraan Circuit Learning lebih baik dibandingkan siswa yang mengikuti model pembelajaran konvensional. Model pembelajaran Circuit Learning dapat melatih siswa untuk mengeluarkan ide dan gagasan baru melalui penemuan yang ditemukannya, sehingga siswa terlatih untuk menemukan hal-hal baru. Penelitian lain yang juga mendukung adalah penelitian yang dilakukan oleh Purwaningrum (2016) yang menyatakan terdapat perbedaan rata-rata antara hasil tes kemampuan koneksi matematis siswa dengan Kriteria Ketuntasan Maksimum (KKM) pada siswa yang belajar melalui Circuit Learning. Circuit Learning dapat mengoptimalkan kemampuan kognitif siswa, mengembangkan sikap berani, dan percaya diri. Siswa terlihat lebih nyaman dan menyenangi pembelajaran.

Berdasarkan uraian yang telah dipaparkan, terlihat jelas bahwa model pembelajaran Circuit Learning berbantuan media flip chart dapat meningkatkan hasil belajar siswa. Model pembelajaran Circuit Learning juga dapat meningkatkan kreativitas siswa dalam merangkai kata dengan Bahasa sendiri dan konsentrasi yang terbentuk membuat siswa fokus dalam belajar. Keberhasilan penelitian-penelitian tersebut mendukung keberhasilan penelitian tentang pengaruh model pembelajaran Circuit Learning berbantuan media flip chart terhadap hasil belajar IPA pada siswa kelas V semester II di SD gugus III Kecamatan Seririt tahun pelajaran 2017/2018. Berdasarkan hal tersebut, model pembelajaran ini dapat diterapkan sebagai variasi dalam kegiatan pembelajaran, sehingga siswa tidak mudah jenuh, pembelajaran menjadi lebih menyenangkan, siswa menjadi lebih aktif dalam belajar, dan pada akhirnya hasil belajar dapat dioptimalkan.

\section{Simpulan dan Saran}

Terdapat perbedaan yang signifikan hasil belajar IPA antara kelompok siswa yang dibelajarkan dengan model pembelajaran Circuit Learning berbantuan media flip chart dan kelompok siswa yang dibelajarkan dengan pembelajaran konvensional pada siswa kelas $\mathrm{V}$ SD di Gugus III Kecamatan Seririt Tahun Pelajaran 2017/2018. Hasil pengujian menunjukkan bahwa thitung $(7,844)$ lebih besar daripada ttabel $(2,014)$ pada taraf signifikansi $5 \%$ dengan $\mathrm{db}=45$.

Model pembelajaran Circuit Learning berbantuan media flip chart berkontribusi dalam meningkatkan hasil belajar IPA siswa yang mana praktek pembelajaran bergeser dari yang berpusat pada guru menjadi berpusat pada siswa, peran guru hanya sebagai fasilitator dan mediator. Siswa diberikan kesempatan untuk berperan secara aktif dan terlibat langsung dalam proses pembelajaran, guru mampu menciptakan suasana yang menyenangkan agar pemahaman yang dialami siswa dapat bertahan lama dalam ingatannya.

Saran yang dapat disampaikan berdasarkan penelitian yang telah dilakukan adalah sebagai berikut. (1) Guru di sekolah dasar hendaknya menerapkan model pembelajaran Circuit Learning berbantuan media flip chart sebagai alternatif dalam meningkatkan hasil belajar siswa. (2) Kepala sekolah hendaknya menugaskan guru-guru untuk ikut dalam pelatihan mengenai pembelajaran inovatif dan mengupayakan untuk menambah media pembelajaran yang relevan dengan pembelajaran di sekolah. (3) Bagi peneliti lain, agar dilakukan penelitian kembali

mengenai pengaruh model pembelajaran Circuit Learning terhadap hasil belajar IPA siswa. Selain itu, dapat dilakukan penelitian pembelajaran Circuit Learning dengan mencari variabel terikat lainnya di tempat penelitian berbeda, karena kajian penelitian yang dihasilkan akan dapat memberikan gambaran yang lebih jelas lagi mengenai keefektifan pembelajaran Circuit Learning terhadap hasil pembelajaran. 


\section{Daftar Rujukan}

Armini, Seni. (2017). "Pengaruh Model Pembelajaran Thik Talk Write Terhadap Hasil Belajar IPA Pada Siswa Kelas IV SD". Jurnal Mimbar PGSD Universitas Pendidikan Ganesha, Volume 5 Nomor 2 (hal 8).

Deporter, Bobbi, Mark Reardon, Sarah Singer Nourie. 2010. Quantum Teaching Mempraktikkan Quantum Learning di Ruang-ruang Kelas. Bandung:Kaifa.

Dewi, Ida Ayu Gede Bintang Praba. 2014. "Perilaku Mencatat dan Kemampuan Memori pada Proses Belajar”. Jurnal Psikologi Udayana, Volume 1, Nomor 2 (hal 248).

Herditiya. 2018. "Pengaruh Penggunaan Media Flipchart Pada Model Learning Cycle Terhadap Hasil dan Aktivitas Belajar Siswa Kelas X Materi Fungi SMA Kemala Bhayangkari. Jurnal Bioeducation, Volume 1, Nomor 1 (hal 25).

Ibrahim. 2017. "Perpaduan Model Pembelajaran Aktif Konvensional (Ceramah) Dengan Cooperatif (Make-AMatch) Untuk Meningkatkan Hasil Belajar Pendidikan Kewarganegaraan". Jurnal IImu Pendidikan Sosial, Sains, dan Humaniora, Volume 3, Nomor 2 (hal 200-202).

Kamelia. 2017. "Meningkatkan Hasil Belajar Siswa Melalui Metode Tanya Jawab Pada Mata Pelajaran IPS di Kelas IV SDN 4 Siboang". Jurnal Kreatif Tadulako Online, Volume 5, No. 7 (hal 151).

Kristiarti, Anastasia. (2015). "Penerapan Model Circuit Learning Dalam Peningkatan Karakter dan Hasil Belajar PKn Tentang Kebebasan Berorganisasi pada Siswa Kelas V SDN 2 Prembun Tahun 2014/2015”. Jurnal Kalam Cendekia PGSD Kebumen, Volume 3, No. 5.1.

Linda, Anna May. 2017. "Efektivitas Model Circuit Learning Untuk Meningkatkan Kreativitas dan Hasil Belajar Ekonomi Siswa SMAN 7 Pontianak". Jurnal Pendidikan dan Pengajaran, Volume 6, No. 5 (hal 2).

Moidady, Nurmila. 2014. "Upaya Meningkatkan Menulis Karangan Sederhana Siswa Kelas IV SDN Pembina Liang Melalui Strategi Aktivitas Menulis Terbimbing". Jurnal Kreatif Tadulako Online, Volume 2, Nomor 2 (hal 81).

Mustafida, Fita. 2017. "Strategi Menciptakan Iklim Kelas Yang Kondusif di SD/MI (Sebuah Kajian Pedagogis, Psikologis)". Jurnal Vicratina, Volume 1, Nomor 2.

Nur, Ninik Dwi. 2013. "Implementasi Pemberian Penguatan Dalam Pembelajaran Kooperatif Tipe Numbered Head Together (NHT) Untuk Meningkatkan Aktivitas dan Hasil Belajar Siswa Pada Sub Pokok Bahasan Operasi Hitung Bentung Aljabar Di Kelas VIIB SMP Negeri 4 Jember Tahun Ajaran 2012/2013". Jurnal Pancaran,Volume 2, No. 1 (hal 210).

Pratiwi, Desi Eka. 2013. "Penerapan Media Papan Balik (Flipchart) pada Pembelajaran Tematik Untuk Meningkatkan Hasil Belajar Siswa Sekolah Dasar". JPGSD, Volume 01 Nomor 02.

Purwaningrum, Jayanti Putri. 2016. "Kemampuan Koneksi Matematis Siswa SD Melalui Circuit Learning". JPSD, Volume 2, Nomor 2. 
Republika. 2015. "Terapkan Metode Pembelajaran Inovatif". Tersedia pada: http://www.republika.co.id/berita/koran/pendidikankoran/15/05/08/no0zs77terapkan-metode-pembelajaran-inovatif. Diakses 19 Januari 2018

Sari, Intan Permata, dkk. 2017. "Pengaruh Penerapan Model Pembelajaran Circuit Learning Terhadap Hasil Belajar Siswa Kelas IV pada Pembelajaran PKn di SDN 10 Surau Gadang". E-Journal Universitas Bung Hatta, Volume 8, Nomor 1.

Sudana, Dewa Nyoman, I Gede Astawan, Nyoman Kusmariyatni, Wayan Rati, Putu Nancy Riastini. 2016. Buku Ajar Perguruan Tinggi Pendidikan IPA SD. Singaraja: Universitas Pendidikan Ganesha.

Susilana, Rudi dan Cepi Riyana. 2007. Media Pembelajaran Hakikat, Pengembangan, Pemanfaatan, dan Penilaian. Bandung: CV Wacana Prima.

Wardika, Komang. 2014. "Pengaruh Model Examples non Examples Terhadap Hasil Belajar IPA Siswa Kls V SD di Gugus III Kecamatan Tampaksiring”. Jurnal Mimbar PGSD Universitas Pendidikan Ganesha, Volume 2, Nomor 1. 